\title{
KAS ELLIPTILINE (NIMISÕNATA) KAASSÕNAFRAAS ON OLEMAS?
}

\author{
Ann Veismann \\ Tartu Ülikool, EE \\ ann.veismann@ut.ee
}

\begin{abstract}
Kokkuvõte. Sõnaliigiliselt on kaassõnade ja määrsõnade klass võrdlemisi erinevad. Kaassõnu on keeles suhteliselt väike ja piiratud hulk, neid tekib aja jooksul küll juurde, kuid kaassõnaks grammatiseerumine muudest sõnaliikidest on pikem protsess. Kaassõna defineerivaks omaduseks on esinemine alati koos nimisõna(fraasi)ga, mille käände kaassõna määrab. Määrsõnade klass seevastu on suur ja heterogeenne, määrsõnu saab hõlpsasti juurde tuletada tuletusliidete abil. Ometi ühendab kaas- ja määrsõnu see, et suur osa kaassõnu võib esineda samas tähenduses ka määrsõnana. Artiklis on uurimise all sõnad, mis võivad esineda nii kaassõna kui ka määrsõnana, säilitades seejuures sama funktsiooni. Kolme sõna (asemele, peale ja läbi) näitel on fookuses kontiinum kaassõna ja määrsõna (ja abimäärsõna) vahel, kus kaassõnafraasi obligatoorseks osaks olev nimisõna(fraas) võib olla kadunud, kuid sisuliselt vähem või rohkem hõlpsasti juurde mõeldav. Selline kontiinum kaassõna, määrsõna ja ühendverbi vahel peegeldab keele paindlikkust ja kõneleja valikuvõimalusi väljenduda võimalikult täpselt vastavalt suhtluseesmärgile.
\end{abstract}

Märksõnad: kaassõnafraas, kaassõnad, määrsõnad, sõnaliigid, süntaks, eesti keel

DOI: https://doi.org/10.12697/jeful.2021.12.1.12

\section{Sissejuhatus}

Kaassõna esmase ja olemusliku definitsiooni juurde kuulub substantiivne komplement: „Kaassõnafraas erineb tüüpilistest fraasidest selle poolest, et fraasi tuumana nõuab kaassõna alati obligatoorset laiendust nimisõnafraasi näol, st kaassõna ei saa mitte kunagi üksi fraasina toimida“ (Erelt 2013: 24). Niisiis on vastus artikli pealkirjas esitatud küsimusele lihtne ja selge „ei“, kui eeldatava kaassõna juurest substantiiv puudub, siis pole tegemist kaassõnaga. Pealkirjana vormistatud küsimus lähtub asjaolust, et teatud hulk muutumatuid sõnu saavad esineda nii kaassõna kui ka adverbina nii, et muutub ainult sõnaliik, tähendus jääb 
samaks (näiteks: Lennuk lendas üle linna (kaassõnafraas) ja Lennuk lendas üle (adverb)) ${ }^{1}$.

Siinse uurimuse eesmärk ongi välja selgitada, millistel asjaoludel sama tähendusega sõna esineb kord kaassõna, kord adverbina; kui suurest ja kui homogeensest/heterogeensest sõnade hulgast saab rääkida, ning kas ja millistel juhtudel saaksime pidada adverbi elliptiliseks kaassõnafraasiks ehk kaassõnafraasiks, mille komplementi eksplitsiitselt pole väljendatud, kuid mis kõneleja ja kuulaja jaoks on implitsiitselt teada.

Selleks olen järjest vaatluse alla võtnud ja süstematiseerinud kõikvõimalikud juhtumid, kus uuritud sõnade sama tähendusega vorm esineb kas koos komplemendiga (kaassõnana) või ilma (adverbina või afiksaaladverbina). Artikli taustaks on laiemalt küsimus, kuidas peaksime grammatikas selliseid juhtumeid käsitlema? Artikli eesmärk on eelkõige kirjeldav ja analüüsiv, mitte preskriptiivne.

Artikkel jaguneb järgmiselt: kõigepealt annan ülevaate probleemi olemusest ja taustast (ptk 2). Alapeatükis 3 selgitan andmete kogumist ja uurimisalust materjali. Seejärel esitan korpusuuringu tulemused, kirjeldades korpusest leitud näidete varal, millal võiks rääkida implitsiitse komplemendiga kaassõnafraasist ja millised on piiriala juhtumid (ptk 4). Pärast näidete esitamist arutlen uurimuse tulemuste üle ja esitan oma seisukohad uurimisküsimustes (ptk 5). Artikli lõpetab kokkuvõte (ptk 6).

\section{Probleemi olemus ja taust}

„Eesti keele seletava sõnaraamatu“ (EKSS) andmetel (päring tehtud jaanuaris 2019) saab eesti keeles kokku lugeda umbes 7578 määrsõna ja 267 kaassõna. Määrsõnade klass on märgatavalt suurem, oluliselt mitmekesisem ja kindlasti ka avatum kui kaassõnade klass. Kuigi ka kaassõnad esindavad grammatiliste, st suletud klassi sõnade seda poolt, mille puhul muutused (grammatiseerumise protsess nimisõnast, verbist

1 Artikkel lähtub sünkroonilistest keeleandmetest. Artiklis ei võeta seisukohta kaassõna ja adverbi kujunemise kohta grammatisatsiooniprotsessis. Adpositsioonid võivad kujuneda nii verbidest kui ka nimisõnadest (Hagège 2010: 151-172). Läänemeresoome keeltes levinud postpositsioonide grammatiseerumise allikaks on enamasti substantiivid (Grünthal 2003). 
või adverbist) on suhteliselt hõlpsalt jälgitavad (nt hiljutisteks kaassõnastujateks võib pidada raames, abil, jõul, toel, viisil jpt, vt Veismann \& Erelt 2017: 450), siis adverbe saab tuletusliidete abil oluliselt kergemalt jooksvalt juurde luua (Reet Kasiku andmetel on regulaarseks määrsõnatuletuseks kasutusel kümmekond liidet, vt Kasik 2015: 381 jj). Seetõttu tuleb võtta ka eelnevalt esitatud adverbide arvu sõnaraamatus pigem tinglikult kui kindlalt.

Eesti keelele kui soome-ugri keelele on omased postpositsioonid, neid on 267 kaassõnast 218. Prepositsioone, mis on eesti keelde tekkinud hiljem (Palmeos 1973: 70), võib EKSSi järgi kokku lugeda 75. Sõnu, mida saab kasutada nii pre- kui ka postpositsioonina, on 26. Enamik neist 26-st on ühtlasi kasutatavad ka adverbina, välja arvatud kolm, kohe 'MURD poole, suunas' ning hiljuti kaassõnastunud vaatamata ja hoolimata (hiljuti grammatiseerunud kaassõnade kohta vt Veismann \& Erelt 2017: 450). Lisaks võib postpositsioonidest 123 sõna kasutada adverbina ja prepositsioonide hulgas on selliseid 42 (ainult prepositsioonina esinevad kuus sõna: keset, kesk, piku 'HRV piki, mööda', tagapidi, teispoole, tänu), kokku teeb see kaassõnade ja adverbide ühisosaks 189 sõna (joonis 1). Teiste sõnadega, kaassõnadest orienteeruvalt $70 \%$ võivad esineda ka adverbina, samas kui adverbidest moodustab kaassõnana esinevate sõnade hulk 2,5\%. Seda seetõttu, et adverbide klass on kaassõnade klassist niivõrd palju suurem ja heterogeensem.

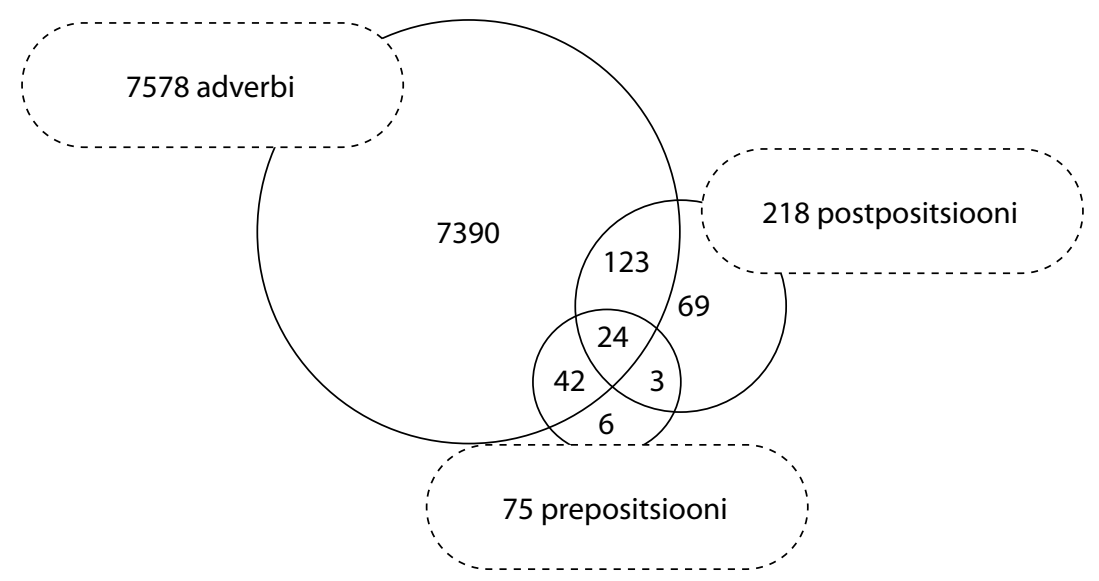

Joonis 1. Adverbide, prepositsioonide ja postpositsioonide hulk ja ühisosad. 
Adverbide ja kaassõnade klassi olemuslik erinevus ja samal ajal ühisosa ei ole ainult eesti keelele (eesti keele grammatikale) omane nähtus. Prepositsioone on eelkõige indoeuroopa keelte kontekstis nimetatud transitiivseteks adverbideks, samuti on püütud eristada primaarseid ja sekundaarseid kaassõnu, viimased võivad esineda ka n-ö intransitiivselt (Hagège 2010: 51-57).

Soome keeleteaduses on kaassõna ja adverbi üleminekuala uurinud Krista Ojutkangas sisä- ja ulko-sõnade näitel (Ojutkangas 2008, 2012). Neist esimesed on primaarselt postpositsioonid, mis võivad esineda adverbina, teised adverbid, mida samas iseloomustavad sis $\ddot{a}$-sõnadega sarnased kasutuskontekstid (nad esinevad koos kohakäändes nimisõnaga ja kohta näitava proadverbiga). Muuhulgas on Ojutkangas täheldanud ulko-sõnade ebatüüpilist kasutust ka kaassõnana (Ojutkangas 2012: 186-187). Ojutkangas näitab, kuidas sisä-sõnade tähendus (ja komplemendi referendi tüüp) on seotud nende sõnaliigilise kasutuskontekstiga, mis moodustab kontiinumi kaassõna, adverbi ja referentsiaalse üksuse vahel (Ojutkangas 2008). Arutledes, miks ulos-sõnad esinevad ainult adverbina (nagu ka eesti keeles välja, väljas, väljast), jagab Ojutkangas ulos-sõnade esinemised samuti komplemendi referentide järgi: referent võib puududa (hevoset ovat ulkona), esineda kohakäändes nimisõnana (tulla ulos talosta) või demonstratiivpronoomenina (tuolla ulkona). Ta näitab, et adverbina kasutus on otseselt seotud referendi varieerumisega, samuti võimalusega diskursuses viidata ja kõneleja/kuulaja tähelepanu erinevalt fookustada (Ojutkangas 2012).

Inglise keele kirjeldavas grammatikas on arutletud kaas- ja määrsõnade klassi osalise kattuvuse probleemi üle praktilisest seisukohast ja lahendusena adverbide klassi kitsendatud ning kaassõnade klassi laiendatud (Huddleston \& Pullum 2002: 562-617). Nende arutluskäik toetub järgmistele asjaoludele. Adverb on kirju jääkklass, millesse sõna satub siis, kui ei vasta teiste sõnaklasside täpsematele määratlustele. Peamine adverbi tunnus on see, et adverb modifitseerib verbi, nii nagu adjektiiv modifitseerib nimisõna (sellest paarid, kus vastavad tuletusliited, nt remarkable ja remarkably). Samas on adverbide hulgas erandlikud kohaadverbid, mis ei modifitseeri verbi (nt downstairs). Üks oluline põhjendus, miks adverbide hulgast osa (traditsiooniliselt) adverbe (sh adverb-prepositsioone) Huddlestoni ja Pullumi grammatikas välja on tõstetud, seisneb selles, et prepositsioonifraasi põhjaks peetakse prepositsiooni, mitte nimisõna, nagu varasemalt. See tähendab, et 
prepositsioonifraasi saab võrrelda teiste fraasidega ja kuigi prepositsiooni esinemine on väga tugevalt seotud tema komplemendiga (harilikult esineb koos komplemendiga), siis komplemendi puudumine on siiski võimalik.

Ka eesti keeles on kaassõnafraasi tuumaks ja süntaktiliseks põhjaks tunnistatud kaassõna, mida obligatoorselt laiendab nimisõnafraas (Erelt 2013: 24, Veismann \& Erelt 2017: 448-449, ptk 13 § 1). Fraasi põhjaks loetakse kaassõna just seetõttu, et kaassõna rektsioon määrab substantiivifraasi olemasolu, paiknemise ja käände. Samal ajal toimib kaassõna teda laiendava täistähendusliku substantiivi(fraasi) suhtes nagu käändetunnus (Erelt 2013: 24, Veismann \& Erelt 2017: 448-449, ptk 13 § 1).

Eesti keele seisukohast lisab probleemile keerukust kaassõnafraasi piiritlemine - komplemendi kääne on üldjuhul kas genitiiv või partitiiv, harvem nominatiiv, kuid teatud juhtudel võib see olla ka muu kääne, näiteks komitatiiv (lastega seltsis), abessiiv (ilma jututa), terminatiiv (kuni lõunani), allatiiv (tänu sõbrale), elatiiv (sügisest saadik) (näited pärinevad „Eesti keele käsiraamatust““ (EKK: M11)).

Samal ajal saab teatud kaassõnadega (nt läbi, üle) moodustada n-ö kaassõnafraasilaadse konstruktsiooni, kus verbi ja adverbiga koos esinev (kohamääruslik) nimisõnafraas on elatiivis, vrd nt kaassõnafraas Tee läheb läbi suure metsa ja kohamääruslik laiend Tee läheb läbi suurest metsast. Vrd ka kaassõnafraasi Suurest metsast alates läks tee ülesmäge. Samasuguseid kasutusi on Ojutkangas näidanud ka soome sisä- ja ulos-sõnadel kaassõna ja adverbi vahelises kontiinumis (Ojutkangas 2008, 2012). Huumo ja Ojutkangas (2010: 25) on nimetanud kohakäändes nimisõnaga koosesinemisi sisä-sõnu analüüsides kvaasikaassõnadeks.

Kohakaassõnade (kui kaassõnade klassi suure ja tüüpilise alamhulga) näitel on probleem kõige nähtavam, kuid kaassõna ja adverbi vaheldus ilmselt ei sõltu kaassõna funktsioonist (vrd: Enne lõunat (kaassõnafraas) oli ilus ilm, aga pärast (määrsõna) hakkas sadama - aega määratlevad enne ja pärast, esimene on kaassõna ja teine määrsõna, kuid võiks olla ka vastupidi: enne (määrsõna) oli ilus ilm, aga pärast lõunat (kaassõnafraas) hakkas sadama). See on tavaline olukord, kus ajamäärusena võib esineda nii määrsõna kui ka kaassõnafraas. Artiklis uurin, millal sama sõna saab kohamäärusena esineda (ilma täpsustava nimisõnalise komplemendita) määrsõnana ja millal kaassõnana (vajades komplementi). Kaassõnade hajus piir nii nimisõnade kui ka adverbidega on 
seletatav grammatiseerumisprotsessiga. Kaassõna ja määrsõna kokkulangemist on nt „Eesti keele käsiraamatus“ selgitatud sellega, et samas käändevormis nimisõna võis esineda koos nii teise nimisõnaga (millest tekkis kaassõna; selgelt läbinähtav on see nt kaassõna asemel puhul) kui ka tegusõnaga, millega koos esinedes tähendus abstraheerus ja tekkis afiksaaladverb (EKK: M 11a).

Järgnevates artikli allosades ongi kolme muutumatu sõna (asemele, peale, läbi) näitel lähemalt uuritud sama sõna esinemist kaassõna ja adverbina.

\section{Andmed}

Et uurida samatähenduslike kaassõnade ja adverbide esinemist kord ühe, kord teise sõnaliigina, olen võtnud vaatluse alla kolm muutumatut sõna: asemele, peale ja läbi. Neist asemele on postpositsioon ja adverb, mille grammatiseerumine on teistega võrreldes toimunud suhteliselt hiljuti ning esialgne nimisõnatähendus on selgelt läbinähtav. läbi on peamiselt prepositsioon ja adverb, kuid võib teatud tähenduses ('kaudu, teel') esineda ka postpositsioonina. peale võib esineda nii prepositsiooni, postpositsiooni kui ka adverbina. Nii läbi kui ka peale on grammatiseerunud kaassõnaks varem kui asemele.

Uuringus olen kasutanud andmeallikana 2019. aasta eesti keele ühendkorpust (Estonian NC, 1500284681 sõna) päringusüsteemi Sketch Engine (Kilgarriff et al. 2004) vahendusel. Tabelis 1 on toodud andmed uuritud sõnade esinemise kohta korpuses sõnaliikide kaupa. Uuritud sõnadest kõige sagedasem on peale adpositsioonina ja kõige vähem sage on asemele adverbina. asemele kaassõnana esineb umbes kolm korda sagedamini kui adverbina. läbi on ainus kolmest, mis on adverbina sagedasem kui kaassõnana (umbes kaks korda sagedasem). Kui peale ja läbi esinemisi miljoni sõna kohta saab loendada sadades, siis asemele on neist oluliselt vähem sage sõna, esinemised miljoni sõna kohta jäävad kümnete piiresse. 
Tabel 1. Sõnade asemele, peale ja läbi esinemised sõnaliikide järgi eesti keele ühendkorpuses 2019 (1 500284681 sõna).

\begin{tabular}{l|c|c|c|c}
\hline \multicolumn{1}{c|}{ Sõna } & $\begin{array}{c}\text { Esinemine } \\
\text { adverbina }\end{array}$ & $\begin{array}{c}\text { Esinemine } \\
\text { adverbina miljoni } \\
\text { sõna kohta }\end{array}$ & $\begin{array}{c}\text { Esinemine } \\
\text { kaassõnana }\end{array}$ & $\begin{array}{c}\text { Esinemine } \\
\text { kaassõnana } \\
\text { miljoni sõna kohta }\end{array}$ \\
\hline asemele & 16393 & 8,96 & 48304 & $\mathbf{2 6 , 4}$ \\
\hline peale & 538181 & 294,15 & 1434064 & $\mathbf{7 8 3 , 8}$ \\
\hline läbi & 1018778 & $\mathbf{5 5 6 , 8 2}$ & 495781 & 270,97 \\
\hline
\end{tabular}

Selleks, et uurida implitsiitse komplemendiga kaassõnafraase, tegin korpusest Sketch Engine'i kaudu konkordantsipäringu lemmadele asemele, peale ja läbi adverbina, päringust tegin 1000-lauselise juhuvalimi. Kodeerisin laused selle järgi, kas uuritava sõna juurde on lausesse võimalik panna komplement, ning kas komplemendiks sobiv sõna on varem nimetatud (samas või eelmises lauses). See tähendab, et lauseid jaotades oli peamine eesmärk selgitada, mil määral on adverb muudetav kaassõnafraasiks ehk kas tegemist võiks olla implitsiitse komplemendiga kaassõnafraasiga. Potentsiaalseteks implitsiitse komplemendiga kaassõnafraasideks arvasin need kasutused, kus võimalik komplement oli nimetatud kas samas või eelmises lauses, mõnikord ka ilmselt varem tekstis, või olla hõlpsalt juurde mõeldav maailmateadmiste põhjal. Selles osas jagunes andmestik selgelt kaheks - asemele andmestik oli valdavalt selline, mida võis pidada n-ö komplemendita kaassõnafraasiks. Seevastu peale ja läbi lausete hulgas oli selliseid kasutusi võrdlemisi vähe. Lisaks leidus andmestikus kasutusi, kus komplemendiks sobiv sõna oli saanud muu (koha)käände: allatiivi asemele ja peale puhul, elatiivi või ablatiivi läbi korral. Eraldi käsitlen näiteid, kus komplement puudub, kuid ühendverbi juures esineb kohta näitav proadverb (siia / sinna asemele; siia / sinna peale; siit / sealt läbi), nimetan neid edaspidi demonstratiivseteks proadverbideks (Erelt 2000: 12-13). Kokku jäi uurimuse jaoks huvipakkuvaid lauseid iga sõna 1000-lauselisest juhuvalimist järgmiselt:

- asemele 925 lauset, millest neli muus käändes komplemendiks sobiva nimisõnaga ja 44 proadverbiga. asemele andmestikus ei olnud selgelt ühendverbiks peetavaid ühendeid. 1000 lause hulgast jäid välja vale märgenduse saanud laused - adverbi asemel oli tegemist kaassõna või nimisõnaga. 
- peale 257 lauset, millest 95 muus käändes komplemendiks sobiva nimisõnaga ja 14 proadverbiga. Ülejäänud lausete puhul oli tegemist kas selgelt (mittekohatähendusliku) ühendverbiga või märgendusvigadega.

- läbi 104 lauset, millest 79 muus käändes komplemendiks sobiva nimisõnaga ja 11 proadverbiga. Ülejäänud lausete puhul oli tegemist kas selgelt (mittekohatähendusliku) ühendverbiga või märgendusvigadega.

Andmete selline jagunemine näitab, et asemele on eelkõige kaassõna ning tema funktsioneerimine adverbina pigem marginaalne, afiksaaladverbina alles kujunemas. Seevastu läbi on adverbina kasutusel eelkõige ühendverbide koosseisus.

Järgnevalt kirjeldan kõikide uuritud sõnade kasutusi täpsemalt. Kõik näited pärinevad eesti keele ühendkorpuse 2019. aasta versioonist.

\section{Uurimistulemused. Elliptilised kaassõnafraasid sõnadega asemele, peale ja läbi}

Analüüsin siin peatükis korpuse valimist leitud näiteid sõnade kaupa. Selleks olen jaotanud leitud näited tüüpideks, mis on esitatud tabelis 2 . Uurimuse fookus on veergude a ja b vahekord, veerud c, $d$ ja e esitavad näiteid sellest, millised sama tähendusega kasutused lisaks kaassõnale ja adverbile veel võimalikud on, ka neid käsitlen artiklis pikemalt. Küsimärk märgib näite vähest või kaheldavat kasutust.

Tabel 2. Võimalikud konstruktsioonid sõnadega asemele, peale, läbi.

\begin{tabular}{c|c|c|c|c|c}
\hline Sõna & $\begin{array}{c}\mathrm{a} . \\
\text { NPgen+postp } \\
\text { Prep+NPgen }\end{array}$ & $\begin{array}{c}\text { b. } \\
\text { Adverb/ } \\
\text { Implitsiitne } \\
\mathrm{NP}\end{array}$ & $\begin{array}{c}\mathrm{c} . \\
\text { NPAll + adv } \\
\mathrm{adv}+\text { NPEla }\end{array}$ & $\begin{array}{c}\mathrm{d} . \\
\text { Proadv }+ \\
\mathrm{adv}\end{array}$ & $\begin{array}{c}\mathrm{e} . \\
\mathrm{V}+\mathrm{afadv}\end{array}$ \\
\hline asemele & $\begin{array}{c}\text { akende } \\
\text { asemele }\end{array}$ & $\begin{array}{c}\text { [millegi] } \\
\text { asemele }\end{array}$ & $\begin{array}{c}\text { ? akendele } \\
\text { asemele }\end{array}$ & $\begin{array}{c}\text { siia / sinna } \\
\text { asemele }\end{array}$ & $\begin{array}{c}\text { asemele } \\
\text { panema }\end{array}$ \\
\hline peale & muhu peale & $\begin{array}{c}\text { [millegi] } \\
\text { peale }\end{array}$ & $\begin{array}{c}\text { muhule } \\
\text { peale }\end{array}$ & $\begin{array}{c}\text { siia/sinna } \\
\text { peale }\end{array}$ & $\begin{array}{c}\text { peale } \\
\text { tulema }\end{array}$ \\
\hline läbi & läbi metsa & $\begin{array}{c}\text { läbi } \\
\text { [millegi] }\end{array}$ & $\begin{array}{c}\text { metsast } \\
\text { läbi }\end{array}$ & $\begin{array}{c}\text { siit/sealt } \\
\text { läbi }\end{array}$ & $\begin{array}{c}\text { läbi } \\
\text { kukkuma }\end{array}$ \\
\hline
\end{tabular}


Veerus a on toodud iga sõnaga näiteks tavaline kaassõnafraas. Veerg $b$ esindab võimalikku implitsiitse komplemendiga kaassõnafraasi. Veerg c esindab näiteid, kus adverbi kõrval esineb konstruktsioonis muus käändes nimisõna, mis genitiivis või partitiivis esinedes muudaks sama fraasi kaassõnafraasiks. Veerg d esindab juhtumeid, kus adverbi (või implitsiitse komplemendiga kaassõna) kõrval paikneb proadverb, mis viitab entiteedi, mida märgiks puuduv komplement, asukohale. Veerg e illustreerib vaadeldud sõnade esinemist afiksaaladverbina. Järgnevalt tuleb igast veerust eraldi juttu.

\section{1. asemele, peale ja läbi hariliku kaassõnana}

Esmalt toon näited iga sõna kohta tavalisest kaassõnalisest kasutusest, kaassõnafraas on märgitud poolpaksu kirjaga, entiteedile viitav sõna, millega kaassõnafraas sisuliselt on seotud, on alla joonitud (1-3).

(1) ASEMELE: $\underline{\text { Uus hokihall rajatakse praeguste parklate asemele. }}$

(2) PEALE: Siis pandi laps kõhuli põlvede peale ja võeti parem käsi ja pahem jalg.

(3) LÄBI: Hetkeks vilksas läbi pea mõte, et mine tea, kas rahutuvi haiseb.

\section{2. asemele, peale ja läbi määrsõnana (komplemendita)}

Järgnevad näited on ilma nimisõnalise komplemendita. Näited jagunevad kolmeks selle järgi, kas (ja kui kaugel tekstis) on komplemendiks sobiv sõna varem nimetatud. Kui komplemendiks sobiv sõna esineb samas või vahetult eelnevas lauses, on tegemist pigem elliptilise kaassõnafraasiga. Kui komplemendiks sobiv sõna on kas varasemast tekstist teada või tuleneb üldisematest teadmistest, läheneb fraas pigem ühendverbile. Minna Jaakola (1997) on märkinud, et genitiivis komplement toimib kaassõnafraasis viitepunktina, sellega viidatakse entiteedile, mille suhtes adpositsiooniga väljendatud suhe kehtib. Kuid viitepunkt võib olla ka väljendamata, kui see selgub kontekstist (Jaakola 1997: 124). 
Kõigepealt esitan näited (4-6), kus võib rääkida implitsiitse komplemendiga kaassõnafraasist. Neid näiteid iseloomustab see, et (kaas)sõna implitsiitse komplemendi referent esineb tekstis varem (näites alla joonitud) ja esitatud näites võiks adverbi hõlpsasti muuta kaassõnafraasiks, lisades adverbi juurde anafoorse (tagasiviitava) pronoomeni (nende, selle, näidetes lisatud nurksulgudes). Just sellised kasutused olid valdavad asemele andmestikus. Järgnevates lausetes on komplemendi sisu üsna selge. Teistest veidi erinev on lause 5a, kus komplemendi täpsem sisu selgub pärast adverbi peale esinemist.

(4) ASEMELE:

a) Terviseprobleemide tõttu lahkus eelmisel nädalal tööpostilt Ivan Fassotte, [tema] asemele tuli John Van De Keere.

b) Sellised puud tuleks Aaspõllu sõnul julgelt välja praakida ja korralikud [nende] asemele istutada.

(5) PEALE:

a) Väga raske [naha] peale kanda, pärast jäi nahk nagu nõgiseks või nii :D

b) Aseta röstitud kartulid taldriku keskele ning [nende] peale suitsuhapukoor koos tilliõliga.

(6) LÄBI: Nii armas ja pehme, kohe mitte ei raatsi ära kinkida. Tegin huvi pärast ka sõrmusega katse, mahtus läbi [selle] küll.

Järgnevates lausetes (7-9) pole kaassõnafraasi komplemendi referent nii selge, kuid on siiski (juurde)mõeldav. Selle sisu on mõistetav tänu kontekstile - kui tekstis varem kõneks olnuga mitte tuttav olla, siis võib lause täpsem tähendus ka mõistetamatuks jääda, nagu näidetes $7 \mathrm{a}, 8$, 9a. Tõenäoline on näitelauses komplemendiks sobiva nimisõna esinemine varasemas tekstis. Kaassõnafraasiks muutmise korral tuleks sel juhul korrata pigem vastavat nimisõna kui asendada see pronoomeniga (näidetes on nurksulgudes antud küsimus komplemendi kohta). Nende näidete puhul pole seos kaassõnafraasiga enam sama selgelt läbinähtav, nagu eelnevates näidetes. Samas pole tegemist ühendverbilaadsete kasutustega - lause mõistmiseks on vajalik teadmine varem nimetatud komplemendist. 
(7) ASEMELE:

a) Mida olekski kohalikul protestantlikult pildivaesel kultuuril lastele [mille?] asemele pakkuda?

b) See tähendab aga, et tuleb luua uusi, paremaid keelendeid [mille?] asemele.

(8) PEALE: Ise uut ei pannud, vaid lasin paiga paksemast torust [mille?] peale keevitada ja 1,5 aastat on juba pidanud.

(9) LÄBI:

a) Kujundeid ette joonistada ei tohi, sest värv on läbipaistev ning piirjooned jäävad läbi [mille?] kumama.

b) - kole ring oleks tulnud teha - ebameeldiv! Väga pikalt ei mõelnudkipaneme otse läbi [mille?]! Nii kiiresti kui saab! Mättalt mättale!

Sõnade peale ja läbi kohta leiab ka näiteid, kus viidatavat entiteeti ei verbaliseerita kaassõnafraasis, sest see ilmneb üldistest maailmateadmistest (10-11). Need juhtumid on lähedased ühendverbidele, milles tähendus on kinnistunud verbiühendi külge (peale võtma 'autoga küüti pakkuma', peale vajuma 'valdama'). Nurksulgudes on pakutud võimalikud tõlgendused kaassõnafraasi komplemendi referendile. Laused on arusaadavad kaassõnafraasi juurde mõtlemata, adverb on struktuuriline valik, mis ei nõua vastava entiteedi nimetamist. Ühendverbist eristab neid näiteid selge võimalus muuta fraas kaassõnafraasiks (vrd ühendverb läbi kukkuma, mille puhul ei saa kaassõnafraasi moodustada: *läbi eksami kukkuma). Ühendverbid ilma teadmiseta, kas nad on muudetavad kaassõnafraasiks või mitte, võivad olla mitmetähenduslikud (läbi kukkuma 'ebaõnnestuma' või 'füüsiliselt langema läbi mingi entiteedi'; peale jääma 'võitma, üle olema' või 'füüsiliselt samasse paika kinnistuma'). Selleks, et näidetes 10a, 10b, 11a toodud ühendverbe mõista, peame me eelnevalt teadma, et jutt käib nimetamata entiteetidest auto, pilt, pea.

(10) PEALE:

a) Sealt tagasitulles võtame kassi Pärnust [auto] peale ja ülejäänud puhkuse veedame kodus puhkusest puhates.

b) Aga eks ma teinekord proovin teiselt poolt pildistada, siis ehk ei jää [pildi] peale. 
(11) LÄBI:

„Isegi siis, kui inimene ei võta kaarti, käib tal mõte läbi [pea], kui ta seda kaarti näeb," selgitas Allikvee.

\section{3. asemele, peale ja läbi koos demonstratiivse proadverbiga}

Järgnevates näidetes (12-14) võiks olla tegemist implitsiitse komplemendiga kaassõnafraasiga, kuid lisaks komplemendi puudumisele paikneb adverbi juures demonstratiivne proadverb, mis viitab samale entiteedile, millele võiks viidata ka nimisõna või pronoomen alternatiivses kaassõnafraasis. Olen alternatiivsed kaassõnafraasid toonud välja näite lõpus nurksulgudes.

(12) ASEMELE:

a) Aga asi on selles, et kui minult tõmmatakse esihammas ära siis on vaja sinna asemele saada implantaati, ... [esihamba asemele]

b) Tomatitel lõika kaas sakiliselt ära ja uurista tomati sisu välja. Sinna asemele pane soolaseentest, sibulast, hapukoorest ja piprast valmistatud täidis. [sisu asemele]

(13) PEALE:

a) Serveeri riis, kalla see laksa kaste sinna peale ning kaunista koriandri lehtedega. [riisi peale]

b) Suure huvi korral võibolla saaks isegi lasta trükkida kleepsuna sellise asja sinna peale. [selle peale]

(14) LÄBI:

a) Getafel liiga parim kaitse, kui Ronaltsi ka veel pole, siis sealt läbi murda on küll väga keeruline. [läbi kaitse]

b) läätspuuhekk, mis küll sügise poole nii harvaks muutus, nagu ma mäletasin, et soovimatu silm võis sealt vabalt läbi kaeda. [läbi heki]

Selles mõttes ei saa pidada proadverbi implitsiitse komplemendi asendajaks, et proadverbiga lausesse on võimalik lisada ka komplement, tehes nii meid huvitavast adverbist kaassõnafraasi (vrd sinna hamba asemele; sinna riisi peale; sealt läbi heki]. Võib oletada, et sellised proadverbi ja implitsiitse komplemendiga kaassõnafraasi kombinatsioonid on tekkinud vajadusest rõhutada komplemendi referendi enda asemel komplemendiga viidatava entiteedi asukohta. Ilmekas näide 
on esimene, kus jutuks on hamba asendamine, kuid demonstratiivne proadverb ei tõsta esile mitte hamba enda asendamist, vaid eemaldatud hambast jäänud tühimiku asendamise. Sellele viitab ka korpusest leitud näide 15 , milles pole kasutatud mitte proadverbi sinna, vaid kohale viitavat kaassõnafraasi sama koha peale. Komplement on sel juhul implitsiitne.

\section{(15) kavatsen sisselangenud katusega elamu pikali lükata ja suvila sama koha peale asemele panna. [elamu asemele]}

Samal ajal säilitab lokatiivse proadverbiga kui demonstratiiviga viitamine diskursuse sidususe: demonstratiive kasutatakse anafoorilisel viitamisel just siis, kui on tarvis teist korda mainida ja referent fookusesse (topikuks) tõsta (Diessel 1999: 98). Teiste sõnadega, kohta näitavad asemäärsõnad (demonstratiivsed proadverbid) saavad viidata anafoorselt tagasi kaassõna komplemendiga tähistatud entiteedile (sest nad on demonstratiivid) ja samal ajal selle entiteedi asukohale (sest nad asendavad kohamäärsõnu). Soome demonstratiivide üleminekuid deiktiliste demonstratiivide ja lokatiivsete adverbide vahel on kirjeldanud Ritva Laury (1996, 1997) ja tema järgi Holger Diessel (1999: 75-78). Eesti keele demonstratiivsed proadverbid on käsitlemist leidnud peamiselt demonstratiividena (nt Pajusalu jt 2020, Keevallik 2011, Sahkai 2003), vähem adverbidena (Taremaa 2017). Demonstratiivsete proadverbide (siin, seal jt) ja demonstratiivpronoomite (see, too) erinevust kasutusel koos kohakäändes nimisõnaga (siin majas vs. selles majas) on lähemalt uurinud Hint jt (2021), Taremaa jt (2021). Nad näitavad, et proadverbi kasutatakse määratlejana just eelkõige koos kohasõnadega.

Taremaa (2017: 459) toob välja, et kui lokatiivne demonstratiivadverb esineb kõrvuti koos kaassõnafraasiga semantiliselt kongruentselt (nt sinna metsa alla), siis on tegemist pigem artiklilaadse funktsiooniga. Ta lisab samas (Taremaa 2017: 460), et kui lokatiivne demonstratiivadverb paikneb semantiliselt kongruentselt kõrvuti afiksaaladverbiga, siis ei saa seda pidada määratlejaks, vaid koos (afiksaal)adverbiga moodustub pigem kaassõnafraasilaadne ühend (nt sinna sisse). Omaette teema oleks uurida juhtumeid, kus lokatiivne demonstratiivadverb ja afiksaaladverb ei paikne kõrvuti, kuid on semantiliselt kongruentsed. Siinses materjalis on selle kohta järelduste tegemiseks liiga vähe näiteid, samuti vajaks semantiline kongruentsus täpsemat määratlemist 
(siinse käsitluse jaoks on sinna asemele, sinna peale, sealt läbi kõik semantiliselt kongruentsed.

\section{4. asemele, peale ja läbi koos muus käändes kvaasikomplemendiga}

Järgnevalt toon välja näited (16-18), kus sõna on loetud adverbiks, sest talle eelnev nimisõna on muus käändes kui tüüpiliselt kaassõnafraasi komplement. Sõna asemele puhul on nimisõna allatiivis, peale juures samuti allatiivis ning läbi on võimalik koos elatiivse kvaasikomplemendiga. Olen nimetanud muus kohakäändes komplemendi kvaasikomplemendiks, nii nagu Ojutkangas ja Huumo (2010) nimetavad selliseid kaassõnu/määrsõnu, mis esinevad koos muus kohakäändes nimisõnaga, kvaasiadpositsioonideks.

(16) ASEMELE:

a) Muidugi sooviksin ka tühjadele kohtadele hambaid asemele.

b) ...nii sai ostetud peese läinud emaplaadile asemele une...

(17) PEALE:

a) Aseta pooltele kuklitele peale kalkunifilee tükk ja tomativiil, ...

b) Pahatihti arvame, et kui tootele on peale kirjutatud "looduskosmeetika", siis ei sisalda see toode midagi kunstlikku.

(18) LÄBI:

a) Läksid kolmest uksest läbi.

b) Aga kuhu? See mõte käis paljudel linlastel peast läbi.

c) Mingi anduriga pole mõtet jamada aga kui ikka suur soov on just voolikust läbi voolavat hulka mõota siis Faria Fuel Manager oleks ilmselt kõige soodsam võimalus.

Toodud näiteid iseloomustab see, et kvaasikomplemendi asemel saaks probleemideta kasutada ka tavalist komplementi (tühjade kohtade asemele, poolte kuklite peale, läbi kolme ukse), tähendus sellest ei muutuks. Siiski ei saa neid juhtumeid lugeda muus käändes komplemendi näideteks, sest kui kaassõnafraasi defineeriv omadus on lahutamatus (nimisõna ja kaassõna ei ole lahutatavad), siis nimisõna ja adverb on lahutatavad (nagu näidetes 16a ja 17b) ning läbi puhul on tavaline 
muutunud sõnajärg. Ka näidetes $16 \mathrm{~b}, 17 \mathrm{a}$ ja $18 \mathrm{a}-\mathrm{c}$ saab nimisõna üsna hõlpsalt adverbist lahutada. Näidetesse 19-21 olen konstrueerinud lisaks mitmesuguseid määrusi (märgitud suurtähtedega), mis lahutavad nn muus käändes komplementi ja adverbi.

(19) ASEMELE: nii sai ostetud peese läinud emaplaadile KOHE asemele иие...

(20) PEALE: Aseta pooltele kuklitele KAUNISTUSEKS peale kalkunifilee tükk ja tomativiil, ...

(21) LÄBI:

a) Läksid kolmest uksest KIIRESTI läbi.

b) Aga kuhu? See mõte käis paljudel linlastel peast LIHTSALT läbi.

c) Mingi anduriga pole mõtet jamada aga kui ikka suur soov on just voolikust IGA PÄEV läbi voolavat hulka mõota siis Faria Fuel Manager oleks ilmselt kõige soodsam võimalus.

Samuti on toodud näidetele enamasti iseloomulik suhteliselt vaba sõnajärg (aseta pooltele kuklitele peale $=$ aseta kalkunifilee tükk peale pooltele kuklitele; mõte käis peast läbi = läbi peast), samas kui kaassõnafraas on kindlalt kas pre- või postpositsioon (hamba asemele, kuklite peale, läbi vooliku). Siiski ei ole sõnajärje varieerumine ja vahele paigutamise võimalus päris piiranguteta. Mis seda täpsemalt määrab, vajaks lähemat uurimist suurema materjali peal. Kuigi vaadeldud näiteid iseloomustab tähenduse muutumatus, võib komplemendi ja muus käändes kvaasikomplemendiga fraaside vahel olla ka oluline tähenduserinevus (nt alla jääma: jäi NP alla 'füüsiliselt millegi alla paiknema' ja jäi NP-le alla 'millestki nõrgem olema, kaotama', mis tuleb sellest, et moodustunud ühendverb kannab tervikuna teist tähendust kui kaassõnafraas ja verb.

\section{5. asemele, peale ja läbi ühendverbina}

Järgnevalt arutlen selle üle, kuidas suhestuvad implitsiitse komplemendiga kaassõnafraasid ühendverbidega. On selge, et ühendverbid ei ole väga kindlate piiridega klass, üleminek vabast adverbist verbi juurde kuuluvaks adverbiks on sujuv nii tähendust kui ka vormi arvestades. 
Veismann ja Sahkai on ühendverbide kategooria määratlemise juures välja toonud neli probleemi, millest siinses kontekstis on olulised kaks: ühendverbe moodustavate afiksaaladverbide kategooria ei ole selgepiiriline ja ühendverbide süntaktiline staatus ei ole selge (Veismann \& Sahkai 2016: 270). Siinse käsitluse jaoks on need kaks probleemi ka selgelt seotud.

Huno Rätsep on jaganud ühendverbid ainukordseteks ja korrapärasteks (Rätsep 1978). Ainukordsetel ühendverbidel ei ole seost implitsiitse komplemendiga, kuna verb ja afiksaaladverb moodustavad sisulise terviku, kus adverb kuulub süntaktiliselt lause verbaalsesse tsentrumisse (nt peale hakkama; Rätsep 1978; Veismann \& Sahkai 2016). Korrapäraste ühendverbidega on keerulisem: nendes on adverb verbi vaba laiend, mille kohta saab esitada eriküsimuse (Õun kukkus puu otsast alla - Kuhu kukkus õn puu otsast? (Rätsep 1978: 29)), st need ei moodusta püsiühendeid (ei kuulu tervikuna lause verbaalsesse tsentrumisse). Samas Mati Erelti järgi „,moodustavad ka korrapärased ühendverbid süntaktiliselt lahutamatu terviku“" (Erelt 2013: 63). Seejuures toob Erelt näiteks, et laiendi vormi määramisel on oluline verbiühend tervikuna, näiteks lauses Sõidab sillast üle määrab laiendi sillast elatiivivormi ühendverb üle sõitma, mitte verb sõitma (Erelt 2013: 63). Kuid selline selgitus paistab tehniline - kvaasikomplement on muus käändes seetõttu, et käände määrab adverbi ja verbi ühend (peale asetama - millele?) ja komplement komplemendikäändes, sest kuulub kaassõnafraasi (asetama - kuhu? Mille peale?). Vaatleme, milliseid verbifraase moodustavad uuritud sõnad.

Selleks olen võtnud Sketch Engine'ist sõnavisandid adverbi ja verbi ühendina kõikide uuritud sõnade kohta ühendkorpuses 2019. Sõnade peale ja läbi loetelus domineerivad selgelt ainukordsed ühendverbid, samas kui asemele moodustab verbiga ühendeid korrapäraselt (verbiühendi tähendus on kahe liidetava (adverbi ja verbi) summa, see ei erine tähenduselt adverbi ja verbi tavatähendustest) (vt tabel 3). Et ka asemele on kasutatav afiksaaladverbina, näitavad mõned korpusest leitud laused, milles sõna korratakse kõigepealt kaassõnana ja seejärel afksaaladverbina (21).

(21) Aga lahkunud spetside asemele tuleb ju kedagi asemele võtta! 
Tabel 3. peale, läbi, asemele koosesinemine verbidega ühendkorpuses 2019 (Sketch Engine'i sõnavisandi järgi).

\begin{tabular}{l|l|l}
\hline $\begin{array}{l}\text { asemele } \\
\text { laiendab verbi }\end{array}$ & $\begin{array}{l}\text { peale } \\
\text { kuulub ühendverbi }\end{array}$ & $\begin{array}{l}\text { läbi } \\
\text { kuulub ühendverbi }\end{array}$ \\
\hline panema & peale_hakkama & läbi_viima \\
\hline istutama & peale_panema & läbi_käima \\
\hline ehitama & peale_tulema & läbi_saama \\
\hline pakkuma & peale_jääma & läbi_lugema \\
\hline ostma & peale_minema & läbi_tegema \\
\hline astuma & peale_suruma & läbi_vaatama \\
\hline tooma & peale_saama & läbi_mõtlema \\
\hline tulema & peale_võtma & läbi_minema \\
\hline keevitama & peale_tegema & läbi_elama \\
\hline hankima & peale_kandma & läbi_sõitma \\
\hline kerkima & peale_maksma & läbi_laskma \\
\hline võtma & peale_valama & läbi_rääkima \\
\hline
\end{tabular}

Peab nõustuma H. Rätsepaga, kes nendib, et ,verbi juurde kuuluvad adverbid ei ole oma olemuselt sugugi homogeensed, vaid on oma semantikalt ja ka süntaktilistelt tunnustelt mitmesugused“" (Rätsep 1978: 29). Kui läbi ja peale sagedasemate ühendite puhul võib üldiselt nõustuda M. Ereltiga, et laiendi käände määrab ühendverb tervikuna, siis asemele puhul see nii ei ole ja ühendverbist enamasti rääkida ei saa. Näiteks lauses lilled tuleb peenrasse asemele istutada korral ei saa ilmselt öelda, et kohamääruse peenrasse vormi määraks ühend (asemele istutama) tervikuna, pigem on määrajaks verb (istutama) üksi.

\section{Järeldused ja diskussioon}

Uurimuse eesmärgiks oli analüüsida juhtumeid, kus sama sõna esineb süntaktiliselt kas kaassõna, adverbi või afiksaaladverbina, ning kindlaks teha, kas ja millal võiksime rääkida kas komplemendita kaassõnafraasist või implitsiitse komplemendiga kaassõnafraasist. Uurimus näitas, et kontiinum, mis moodustub kaassõna ja afiksaaladverbi vahel, on sujuvate üleminekutega ning nende üleminekute hulka kuulub ka võimalus jätta ära eksplitsiitne komplement kaassõna eest, kui 
a) (suhtlus)kontekst võimaldab komplemendi osutuse tuvastamist või

b) suhtluses on oluline rõhutada komplemendiga viidatud entiteedi asukohta, mitte komplemendi referenti ennast.

Näited peatükis 4.2 kinnitasid, et komplementi saab kaassõnafraasist hõlpsasti välja jätta juhul, kui see on kas varem mainitud või üldiselt kõnelemiskontekstist teada. Sel juhul asendub kaassõnafraas adverbiga, kuid adverb on lihtsalt kaassõnafraasiks muudetav-mõeldav. Eriti tavalised on sellised kasutused sõnaga asemele. Kaassõnafraasiks muutmise korral sobib enamasti komplemendiks ka tagasiviitav pronoomen (selle, tema, nende).

Tagasiviitamisega on tegemist ka juhtudel, kus kaassõnafraasis komplemendiga viidatava entiteedi asemel on oluline esile tuua selle (varem kõneks olnud) entiteedi asukoht. Sellises funktsioonis sobib lausesse demonstratiivne proadverb (sinna, seal, siit). Proadverbide ühtaegu demonstratiivne ja lokatiivne kasutus vajaks põhjalikumat uurimist (nagu soome keeles Laury 1997, kuid vaata siiski Pajusalu 1999, Pajusalu jt 2020, Taremaa 2017, Hint jt 2021, Taremaa jt 2021). Ojutkanga andmetel (2012) esinevad soome sisä-sõnad adverbina kõige sagedamini ilma komplemendita (156 juhtumit $258 \mathrm{st}$ ) ja sageduselt järgmisena koos demonstratiiviga (andmestikus 74 korda 258-st). Minu andmestik näitas sõnade asemele, peale ja läbi puhul, et demonstratiividest enam esines adverbina kasutusi koos muus käändes komplemendiks sobiva nimisõnaga.

Adverbiks loetakse sõna ka juhul, kui komplemendiks sobiv nimisõna esineb muus käändes (näidetes elatiiv ja allatiiv). Soome kaassõna läpi semantikat kognitiivse grammatika abil selgitades on Pentti Leino (1993) peatunud ka läpi kasutusel adpositsiooni ja adverbina. Kasutades kognitiivse grammatika mõisteid muutuja ja pidepunkt, selgitab ta, kuidas pidepunkt, mis kaassõnafraasis on väljendatud komplemendina, ilmneb läpi adverbina kasutuste korral kas muust kontekstist (sel juhul võib pidepunkt olla nt lauses subjekti rollis (Hormi laskee kipinat läpi 'Lõõr laseb suitsu läbi') või on väljendatud elatiivis määrusena. Leino väidab, et elatiivse määrusena väljendatakse pidepunkti juhul, kui see ei näita mitte liikumisteed, nagu kaassõna läpi komplemendina, vaid mingit takistust muutuja liikumise teel, sellega samapaiksust (nt Päivä paistaa katosta läpi 'päike paistab katusest läbi'). Ka siinse uurimuse põhjal vajaks uurimist semantilised erisused kvaasikomplemendi ja komplemendi kasutamise vahel, samuti komplemendi väljajätmise seos 
komplemendiks sobiva sõna esinemisena lauses subjekti, nagu näites (22), või objektina. Selleks tuleks koguda vastav suurem andmestik kui praegune laiem, mitmekesisemaid näiteid hõlmav andmestik.

\section{(22) Ö̈̈ jooksul suudab piir läbi lasta ligikaudu 30 autot [...].}

Kohakäänete ja komitatiivi esinemise üle komplemendi käändena on arutelnud ka R. Grünthal laiemas läänemeresoome keelte kontekstis (2003: 68-74). Ühelt poolt toetab selliste juhtumite adpositsiooniks lugemist see, et grammatikad nimetavad mitmeid kaassõnu, mille komplement on komitatiivis või mõnes kohakäändes, teiselt poolt ei täida sellised esinemised kaassõnafraasi lahutamatuse tingimust (vt ka Ojutkangas \& Huumo 2010: 26 sisä-sõnade kohta, mille hulgas mõned on kvaasiadpositsioonina esinemisele altimad kui teised). Tähelepanu väärib ka see, et kui eesti läbi pre- ja postpositsiooniline kasutus on selgelt tähenduslikult eristunud nii, et kohatähendust väljendab prepositsioon (vt ka Ruutma jt 2016: 103), siis elatiivse kvaasikomplemendiga näib läbi eelistavat postpositsioonilist asetust. Samas soome läpi kasutus pre- ja postpositsioonina on küll semantiliselt diferentseeritav, kuid siiski mõlemal juhul kohatähenduslik (vt Huumo 2013, Lehismets 2014).

Afiksaaladverbe analüüsides võib täheldada samuti nagu varasemad uurijad, et afiksaaladverbide klass ei ole ühtlane, vaid varieerub nii semantiliselt (tähenduse kompositsionaalsus või idiomaatilisus) kui ka süntaktiliselt (määrates laiendi vormi vähemal või rohkemal määral). Nagu Veismann ja Sahkai on varem möönnud, on rida sõnu, mis jäävad adverbi ja afiksaaladverbi vahele (nt asemele, eest, kallale, kaugele, keskele, kohale, kõrgele, külili, lagedale, lähedale, madalale, mujale, väljast, ülevalt jpt). Neid kõiki loetakse adverbideks, kuid verbiga koosesinemine on nii korrapärane, et afiksaaladverbide loetellu nad hästi ei sobitu (vt Veismann \& Sahkai 2016: 271). Siinne uurimus näitas, et ka ainukordse ühendverbi koosseisus esinevad sõnad (nagu peale ja läbi) võivad olla kasutatud korrapärasemates ühendites.

Verbiühendi ja kaassõnafraasi üleminekust on juttu ka inglise keele kontekstis (vt Debras 2010). Huddlestoni ja Pullumi järgi on inglise phrasal verb liiga hägusalt ja süntaksikeskselt defineeritud ning nad panevad ette nimetada vastavad ühendid, milles verb võtab komplemendiks adverb-prepositsiooni „prepositsioonilisteks verbideks“. See- 
juures saab prepositsioon olla „täpsustamata“ (unspecified), sel juhul on tegemist tavapärase kaassõnafraasiga (mida saab asendada teise kaassõnafraasiga, nt verbi flew juurde võib kuuluda nii to kui ka from kaassõnaga fraas), või „täpsustatud“ (specified), sel juhul nõuab verb enda juurde kindlat prepositsiooni ja nad koos määravad komplemendi (nt refere nõuab enda juurde to) (Huddleston \& Pullum 2002, vt ka Debras 2010: 7). Kuigi verbipartiklitel ja prepositsioonidel saab vahet teha mitmete süntaktiliste testide abil, on tegemist kontiinumiga ja näiteks D. Bolinger on nimetanud üht vahepealset olekut adprep'iks (Bolinger 1971). Adprep ilmutab testides nii prepositsiooni kui ka verbipartikli omadusi, kaldudes pigem siiski prepositsioonide poole. Elisabeth O’Dowdi (O’Dowd 1998) järgi on nii prepositsioonid kui ka kõnealused adverbid pragmaatiliste faktorite ja diskursuse funktsioonide teenistuses. Prepositsioonide funktsioon on sidumine, nad tutvustavad kontekstiliselt uut infot. Partiklid (adverbid) seevastu on seotud seisundi või seisundimuutusega ja seega rohkem verbiga.

\section{Kokkuvõte}

Artiklis analüüsiti üleminekualasid kaassõna, määrsõna ja abimäärsõna vahel. Kui määrsõnade hulgas moodustavad kaassõnadena esinevad sõnad väga väikese hulga, siis kaassõnadest suur osa (70\%) esineb ka määrsõnana. Artikkel lähtub eeldusest, et grammatika teenib suhtluse huvisid ja see, millises sõnaliigis üks või teine keelend konkreetses kõnevoolus realiseerub, sõltub paljudest faktoritest.

Täpsemalt uuriti artiklis muutumatuid sõnu asemele, peale, läbi, mis võivad esineda nii kaassõna (komplemendiga) kui ka määrsõnana (ilma komplemendita), kuid määrsõnalise esinemise juurde on võimalik mõelda implitsiitne komplement. Uurimuse andmestiku moodustas 1000 juhuslikku lauset nende sõnade adverbilise kasutusega 2019. aasta ühendkorpusest. Kaassõnafraasi ja adverbi vahel saab kirjeldada üleminekuala, kus kaassõnafraasi komplement on implitsiitne. Implitsiitne komplement on lause vastuvõtjale tuvastatav kolmel moel: a) komplemendiks sobiv sõna võib olla nimetatud kas samas või eelnevas lauses; b) komplement võib olla nimetatud varasemas tekstis; c) komplement on juurdemõeldav tänu üldistele maailmateadmistele (need näited sarnanevad ühendverbidega ning neid leidub kõige enam 
sõnadega peale ja läbi). Lisaks asetuvad selgepiiriliste kaassõnafraaside ja adverbide vahele juhtumid, kus: d) adverbi asemele, peale, läbi juures esineb kohakäändes nimisõna, mis genitiivis või partitiivis esinedes täidaks komplemendi rolli; e) adverbi juures esineb demonstratiivne proadverb (nt sinna), mis viitab puuduva komplemendi referendi asukohale.

Artiklis arutleti ka samade sõnade esinemise üle afiksaaladverbina asemele moodustab verbiga ühendeid korrapäraselt, samas kui peale ja läbi esinevad enamasti ainukordsete ühendverbide koosseisus (kuid saavad esineda ka korrapäraselt). Võib öelda, et kaassõna/adverbi kontiinumi äärmuses paiknevad ainukordsed ühendverbid, mille puhul verb ja afiksaaladverb moodustavad tähendusliku terviku ega ole enam seotud juurdemõeldava komplemendiga.

Kokkuvõtvalt võib öelda, et sõnaliigiline ähmasus kaassõna, määrsõna ja ühendverbi vahel peegeldab keele paindlikkust ja kõneleja valikuvõimalusi väljenduda täpselt vastavalt suhtluseesmärgile. Keel on pidevas balansseerimises süstemaatilisuse ja väljendusrikkuse vahel ja siin uurimuses välja toodud näited kinnitavad seda, et sama sõna esinemine kord kaassõnana, kord määrsõnana on seotud paindliku valikuga, kas kaassõna komplementi on vaja eksplitsiitselt esile tuua või selgub implitsiitseks jääva komplemendi referent kõnelemise käigus mujalt.

\section{Kirjandus}

Bolinger, Dwight. 1971. The phrasal verb in English. Cambridge: Harvard University Press. https://doi.org/10.1075/tsl.42.

Debras, Camille. 2010. Prepositions and particles in English. How is there a gradient between the two? Cercles, Occasional Papers (2010). 1-14.

Diessel, Holger. 1999. Demonstratives: Form, function and grammaticalization. Amsterdam/Philadelphia: John Benjamins Publishing Company.

EKK $=$ Erelt, Mati, Tiiu Erelt \& Kristiina Ross. 2007. Eesti keele käsiraamat. Tallinn: Eesti Keele Instituut. https://www.eki.ee/books/ekk09/index.php?p=2.

EKSS = Langemets, Margit, Mai Tiits, Tiia Valdre, Leidi Veskis, Ülle Viks \& Piret Voll (toim.). Eesti keele seletav sõnaraamat I-VI (,,Eesti kirjakeele seletussõnaraamatu” 2., täiendatud ja parandatud trükk). Tallinn: Eesti Keele Sihtasutus. http://www.eki.ee/dict/ekss/ekss.html. (9. jaanuar 2019.)

Erelt, Mati. 2000. On the pro-forms in Estonian. Mati Erelt (toim.) Estonian: Typological studies IV (Tartu Ülikooli eesti keele õppetooli toimetised 14). 7-18. Tartu: Tartu Ülikool. https://dspace.ut.ee/handle/10062/40522. 
Erelt, Mati. 2013. Eesti keele lauseõpetus. Sissejuhatus. Öeldis (Tartu Ülikooli eesti keele osakonna preprindid 4). Tartu: Tartu Ülikool. https://dspace.ut.ee/handle/10062/34069.

Grünthal, Riho. 2003. Finnic adpositions and cases in change. Suomalais-Ugrilaisen Seuran Toimituksia 244. Helsinki: Suomalais-Ugrilainen Seura.

Hagège, Claude. 2010. Adpositions. Oxford: Oxford University Press. https://doi. org/10.1093/acprof:oso/9780199575008.001.0001.

Hint, Helen, Piia Taremaa, Maria Reile \& Renate Pajusalu. 2021. Demonstratiivpronoomenid ja -adverbid määratlejatena. Miks me oleme siin ilmas, selles olukorras? Eesti ja soome-ugri keeleteaduse ajakiri. Journal of Estonian and FinnoUgric Linguistics 12(1). 79-111. https://doi.org/10.12697/jeful.2021.12.1.03.

Huddleston, Rodney \& Geoffrey K. Pullum. 2002. The Cambridge grammar of the English language. Cambridge: Cambridge University Press. https://doi.org/10.1017/ 9781316423530 .

Huumo, Tuomas. 2013. Many ways of moving along a path: What distinguishes prepositional and postpositional uses of Finnish path adpositions? Lingua 133. 319 335. https://doi.org/10.1016/j.lingua.2013.05.006.

Jaakola, Minna. 1997. Genetiivin kanssa esiintyvien adpositioiden kieliopillistumisesta. Tapani Lehtinen \& Lea Laitinen (toim.), Kieliopillistuminen: tapaustutkimuksia suomesta (Kieli 12), 121-156. Helsinki: Helsingin yliopiston suomen kielen laitos.

Kasik, Reet. 2015. Sõnamoodustus (Eesti keele varamu I). Tartu: Tartu Ülikooli kirjastus. https://dspace.ut.ee/handle/10062/50084.

Keevallik, Leelo. 2011. Pro-forms as projective devices in interaction. Discourse Processes 48(6). 404-431. https://doi.org/10.1080/0163853X.2011.559150.

Kilgarriff, Adam, Pavel Rychlý, Pavel Smrž \& David Tugwell. 2004. The Sketch Engine. Geoffrey Williams \& Sandra Vessier (toim.), Proceedings of the 11th EURALEX International Congress, 105-115. Lorient: Université de Bretagne Sud.

Laury, Ritva. 1996. Pronouns and adverbs, figure and ground: The local case forms and locative forms of the Finnish demonstratives in spoken discourse. Timo Haukioja, Marja-Liisa Helasvuo \& Elise Kärkkäinen (toim.), SKY 1996 Yearbook of the Linguistic Association of Finland, 65-92. http://www.linguistics.fi/julkaisut/ sky1996.shtml.

Laury, Ritva. 1997. Demonstratives in interaction: The emergence of a definite article in Finnish (Studies in Discourse and Grammar 7). Amsterdam, Philadelphia: John Benjamins Publishing Company. https://doi.org/10.1075/sidag.7.

Lehismets, Kersten. 2014. Suomen kielen väylää ilmaisevien adpositioiden yli, läpi, kautta ja pitkin kognitiivista semantiikkaa (Dissertationes linguisticae Universitatis Tartuensis 21). Tartu: Tartu Ülikooli Kirjastus. https://dspace.ut.ee/handle/10062/42980.

Leino, Pentti. 1993. Polysemia - kielen moniselitteisyys (Kieli 7). Helsinki: Helsingin yliopiston suomen kielen laitos. http://hdl.handle.net/10138/292434.

O’Dowd, Elisabeth M. 1998. Prepositions and particles, a discourse-functional account. New York: Oxford University Press. 
Ojutkangas, Krista. 2008. Mihin suomessa tarvitaan sisä-grammeja? Virittäjä 112(3). 382-400. https://journal.fi/virittaja/article/view/40680/10106.

Ojutkangas, Krista. 2012. Ikkuna ulos. Suomen ulko-grammit ja huomion ikkunoiminen. Virittäjä 116(2). 169-197. https://journal.fi/virittaja/article/view/6567/5377.

Ojutkangas, Krista \& Tuomas Huumo. 2010. Mikä erottaa muodot sisällä ja sisässä? „Synonyymisten“ muotojen analyysi. Sananjalka 52. 19-45. https://journal.fi/sananjalka/article/view/86695/45443.

Pajusalu, Renate. 1999. Deiktikud eesti keeles (Dissertationes philologiae estonicae Universitatis Tartuensis 8). Tartu: Tartu Ülikooli Kirjastus. http://hdl.handle. net/10062/39427.

Pajusalu, Renate, Helen Hint, Maria Reile \& Piia Taremaa. 2020. Eesti keele viitevahendid kirjeldustes ja jutustuses. Keel ja Kirjandus 4. 313-335.

Palmeos, Paula. 1973. Eesti keele grammatika II. Neljas vihik. Kaassõna. Tartu: Tartu Riiklik Ülikool.

Ruutma, Mirjam, Aki-Juhani Kyröläinen, Maarja-Liisa Pilvik \& Kristel Uiboaed. 2016. Ambipositsioonide morfosüntaktilise varieerumise kirjeldusi kvantitatiivsete profiilide abil. Keel ja Kirjandus 2. 92-113.

Rätsep, Huno. 1978. Eesti keele lihtlausete tü̈̈bid. Tallinn: Valgus. http://hdl.handle. net/10062/28159.

Sahkai, Heete. 2003. Demonstrative doubling in spoken Estonian. Trames 7(2). 120-144.

Taremaa, Piia. 2017. Lokatiivsete demonstratiivadverbide asetusest ja funktsioonidest liikumist väljendavate klauside näitel. Keel ja Kirjandus 6, 453-468.

Taremaa, Piia, Helen Hint, Maria Reile \& Renate Pajusalu. 2021. Constructional variation in Estonian: Demonstrative pronouns and adverbs as determiners in noun phrases. Lingua 254. https://doi.org/10.1016/j.lingua.2021.103030.

Veismann, Ann \& Mati Erelt. 2017. Kaassõnafraas. Mati Erelt \& Helle Metslang (toim.), Eesti keele süntaks (Eesti keele varamu III), 446-462. Tartu: Tartu Ülikooli kirjastus. http://www.digar.ee/id/nlib-digar:381010.

Veismann, Ann \& Heete Sahkai. 2016. Ühendverbidest läbi prosoodia prisma. Eesti Rakenduslingvistika Ühingu aastaraamat 12. 269-285. http://dx.doi.org/10.5128/ ERYa12.

\footnotetext{
Abstract. Ann Veismann: Can we speak about adpositional phrases without complements? The aim of the present study is to examine the continuum between adpositions and adverbs in Estonian. The paper focuses on three words that can be used with the same meaning either as adpositions or as adverbs: asemele 'instead of [allative case]', peale 'onto' and läbi 'through'. Data for the study was collected from the Estonian National Corpus 2019 via Sketch Engine. Adpositional phrases without a complement encompass the following possibilities: a) a complement noun is mentioned in the same or the previous sentence; b) a complement noun has occurred somewhere in the foregoing text; c) a suitable complement noun can be established from general knowledge
} 
about the world; d) phrases with a quasi-complement, e.g. with a noun that could be a complement even though it is not in complement case (genitive) but in a local case (elative or allative); e) phrases with a demonstrative pro-adverb which refers to the place of the complement entity. The study also discusses verb-particle combinations with the same adverbs. Verb-particle combinations with asemele are more typical combinations than those with peale and läbi which usually form more idiomatic phrasal verbs. One implication of this study is that the continuum between the adposition and adverb reveals the linguistic flexibility which enables language users the possibility of expressing themselves exactly according to the needs of the communication situation.

Keywords: adpositional phrase, adpositions, adverbs, word class, syntax, Estonian 